Jap. J. M. Sc. \& Biol., 13, 113-119, 1960

\title{
CHEMISTRY OF PHOSPHATIDE AND WAX D OF MYCOBACTERIUM TUBERCULOSIS BCG IN ONE WEEK CULTURE
}

\author{
EIKO KONDO \\ Department of Chemistry, National Institute of Health, Tokyo
}

(Received : June 30th, 1960)

\begin{abstract}
"Purified wax" as isolated by Anderson (1929), is a complex lipid extracted with chloroform from cultures of acid fast bacilli. Extracting the purified wax with boiling acetone, Asselineau (1951) obtained a soluble portion termed "Wax C" and an insoluble residue, the "Wax D" fraction. Likewise, the alcohol-ether soluble part of acid fast bacilli was classified into several fractions. "Phosphatide" is a boiling acetone insoluble residue in the alcohol-ether soluble fraction, corresponding to Wax D of the alcohol-ether insoluble and chloroform soluble fraction. Therefore, the substances contained in Wax $\mathrm{D}$ can be migrated from "phosphatide" depending on the conditions of extraction and on the metabolic stage of bacterial cells.

Works in this laboratory elucidated the chemical components of Wax A, C (Tsumita, $1956 \mathrm{a}, \mathrm{b}$ ) and Wax D (Nojima, $1959 \mathrm{a}, \mathrm{b}$ ) of BCG in 4-6 weeks culture. In this experiment a special consideration was paid on the migration of substances in Wax D from "phosphatide" depending on the extracting condition and on the age of the culture. Therefore, the present author intended to compare the yield and some chemical natures of "phosphatide" with those of Wax D in one week as well as in 4 weeks culture of the bacterial cells. The data of the latter were already precisely reported though its chromatographic fractionation has not been described (Nojima et al., 1958).

Substances containing phosphorus in "phosphatide" and Wax D will play an important role in the metabolic process of lipid in Mycobacterium. After chromatographic partitioning of these fractions phosphorus and inositol contents were analyzed and compared. On the other hand, special emphasis was placed on the yield of cord factor contained in Wax $\mathrm{D}$ depending on the age of the culture.
\end{abstract}

\section{RESULTS}

The production of the bacterial cultures and other materials and methods were described in the previous paper (Nojima, 1959 a). In this work the incubation lasted for one week. $4 \mathrm{w}$ and $1 \mathrm{w}$ mean the culture of 4 weeks and one week, respectively. $1 \mathrm{w}-1,1 \mathrm{w}-2$ and $1 \mathrm{w}-3$ mean Lot 1, 2 and 3, respectively, of the one week culture. "Phosphatide" means the fraction, alcohol-ether soluble, boiling acetone insoluble, being discriminated from phosphatide of chemical designation.

近藤鎣子（国立予防衛生研究所化学部） 


\section{The Yields of Phosphatide and of Wax D in One Week Culture of $B C G$}

The total yield of bacterial cells in one week culture after lyophilization was $0.9 \mathrm{~g} / \mathrm{l}$ on average, while that of 4 weeks culture was $5 \mathrm{~g} / 1$ (Nojima et al., 1958).

Table 1 presents some examples of the yields of phosphatide and of Wax D in one week culture of BCG. For comparison, the yields of other fractions are also indicated.

Table 1. The yield of lipid in one week culture of BCG

\begin{tabular}{lrcccccc}
\hline Culture & Fat & Wax A & Phosphatide & Wax B & Wax C & Wax D & Total lipid \\
\hline $4 \mathrm{w}$ & 12.0 & 5.0 & 0.5 & 3.0 & 3.0 & 1.5 & 25.0 \\
$1 \mathrm{w}-1$ & 3.9 & 1.7 & 1.1 & 1.1 & 1.0 & 0.8 & 9.6 \\
$1 \mathrm{w}-2$ & 4.4 & 1.0 & 1.1 & 2.5 & 0.3 & 0.5 & 9.8 \\
$1 \mathrm{w}-3$ & 2.2 & 1.0 & 0.6 & 1.1 & 1.5 & 2.0 & 8.4
\end{tabular}

$4 \mathrm{w}: 4$ weeks culture (Nojima et al., 1958).

$1 \mathrm{w}-1,2,3$ : One week culture Lot $1,2,3$, respectively.

The yield percentage is expressed as calculated from lyophilized cells.

The results to be noticed was the following: 1 . The yield of neutral fat in 4 weeks culture was extremely large resulting in much larger yield of total lipid than in one week culture. 2. Phosphatides contained in "phosphatide" and Wax D fraction were richer in one week culture than in 4 weeks culture. Phosphorus content in "phosphatide" plus Wax D was greater in one week culture than in 4 weeks culture (Table 2).

Table 2. Phosphorus content in each lipid fraction of BCG in one week culture

\begin{tabular}{cccccccc}
\hline Culture & Fat & Wax A & Phosphatide & Wax B & Wax C & Wax D & $\begin{array}{c}\text { Sum of Wax D } \\
\text { and phosphatide* }\end{array}$ \\
\hline $4 \mathrm{w}^{* *}$ & 0.00 & 0.00 & $\begin{array}{c}2.73 \\
(1.37)\end{array}$ & - & 0.00 & $\begin{array}{c}0.80 \\
(1.2)\end{array}$ & $(2.57)$ \\
$1 \mathrm{w}-1$ & 0.13 & 0.08 & $\begin{array}{c}3.77 \\
(4.14)\end{array}$ & 1.06 & 0.00 & $\begin{array}{c}1.03 \\
(0.83)\end{array}$ & $(4.97)$ \\
$1 \mathrm{w}-2$ & 0.06 & 0.00 & $\begin{array}{c}3.97 \\
(4.37)\end{array}$ & 0.18 & 0.13 & $\begin{array}{c}0.31 \\
(0.16)\end{array}$ & $(4.53)$ \\
$1 \mathrm{w}-3$ & 0.11 & 0.12 & $\begin{array}{c}3.49 \\
(2.09)\end{array}$ & 1.30 & 0.06 & $\begin{array}{c}2.18 \\
(4.36)\end{array}$ & $(6.45)$ \\
\hline
\end{tabular}

Figures shown are percentage content of phosphorus in each fraction.

Figures in parentheses are percentage of phosphorus $\times 10^{2}$ per dry weight of bacterial cells.

* Sum of phosphorus content in Wax D and phosphatide expressed as percentage to dry weight of bacterial cells.

** cited from Nojima et al. (1958).

Some analytical data of these fractions are shown in Table 3.

\section{Chromatographic Partitioning of Wax D in One Week Culture of BCG}

Wax D of BCG in one week culture was chromatographed (Table 4) in the same way as in the case of 4 weeks culture described in the previous report (Nojima, 1959 a). 
Table 3. Several analytical data of lipid fractions in one week culture of BCG (1w-1)

\begin{tabular}{lcccccc}
\hline & Fat & Wax A & Phosphatide & Wax B & Waw C & Wax D \\
\hline P \% & 0.13 & 0.08 & 3.77 & 1.06 & 0.00 & 1.03 \\
N \% & 0.28 & 0.25 & 0.96 & 0.26 & 0.05 & 0.31 \\
Inositol \% & 0.05 & 0.02 & 4.17 & 0.47 & 0.00 & 2.57 \\
\hline
\end{tabular}

Table 4. Chromatography of $0.3 \mathrm{~g}$ of Wax D of $1 \mathrm{w}-\mathrm{BCG}$ dissolved in chloroform, absorbed on $6.6 \mathrm{~g}$ of Silicic acid and $3.3 \mathrm{~g}$ of Hyflosupercel

\begin{tabular}{|c|c|c|c|c|c|c|c|}
\hline Fraction & $\begin{array}{l}\text { Tube } \\
\text { No. }\end{array}$ & Eluted with $50 \mathrm{cc}$ of & $\underset{(\mathrm{mg})}{\text { Weight }}$ & mp. ${ }^{\circ} \mathrm{C}$ & $\mathrm{P} \%$ & $\mathrm{~N} \%$ & $\begin{array}{c}\text { Inositol } \\
\%\end{array}$ \\
\hline & & Original & 300 & $48-73$ & 1.03 & 0.31 & 2.57 \\
\hline \multirow{2}{*}{ "A " } & $1-3$ & Chloroform-methanol $98: 2$ & 10 & $27-31$ & - & - & - \\
\hline & $4-10$ & Chloroform-methanol $93: 7$ & 226 & $43-44.5$ & 0.31 & 0.01 & 0.00 \\
\hline \multirow{2}{*}{ "B" } & $\int 11-14$ & Chlorofrom-methanol $78: 22$ & 42 & $>225$ & 1.70 & 0.00 & 2.28 \\
\hline & $15-18$ & Chlorofrom-methanol $48: 52$ & 36 & $\begin{array}{c}220 \\
\text { (decomp.) }\end{array}$ & 1.80 & 0.09 & 5.02 \\
\hline
\end{tabular}

In the case of 4 weeks culture the fraction " $\mathrm{A}$ " as demonstrated in Table 4 contained cord factor which was identified by rechromatography (Florisil-Hyflosupercel $2: 1$, ethermethanol 9:1). In the present case, fraction " A " contained cord factor as identified by infrared spectrum (Fig. $1,1 \mathrm{w}-1,1 \mathrm{w}-2$ and $1 \mathrm{w}-3$ ) using tube No. 4 for $1 \mathrm{w}-1$, No. 3 for $1 \mathrm{w}-3$ and whole substance for $1 \mathrm{w}-2$. These tubes showed the maximum yield of the first peak of the chromatography. Although some contaminants containing phosphorus and a negligible amount of nitrogen can be expected, the fraction "A" can represent "cord factor fraction", as evidenced by the absorption of infrared spectrum identical to that of the standard (Fig. 1). Fraction "B" contained oligomannoinositide in the case of 4 weeks culture (Nojima, 1959 a).

Since a negligible amount of hexose was detected in Wax C (Table 5), the total yield of cord factor is considered to have been restricted in Wax D in the present experiment. The amounts of "cord factor fraction" in fraction "A" of Table 4 were compared with each other among $4 \mathrm{w}, 1 \mathrm{w}-1,1 \mathrm{w}-2$ and $1 \mathrm{w}-3$ (Table 5). As seen in the table, the amount of " cord factor" remained constant $(0.5-0.6 \%$ to dry weight of bacterial cells) regardless of culture age.

\section{Chromatographic Partitioning of "Phosphatide" Fraction in One Week and 4 Weeks Culture of $B C G$}

"Phosphatide" fraction, alcohol-ether soluble and boiling acetone insoluble, of BCG in one week as well as in 4 weeks culture was chromatographed. The yield patterns are presented in Figs. 2 and 3. Three main peaks were obtained. The tubes of the maximum yield in each peak were subjected to several chemical analyses (Table 6). 

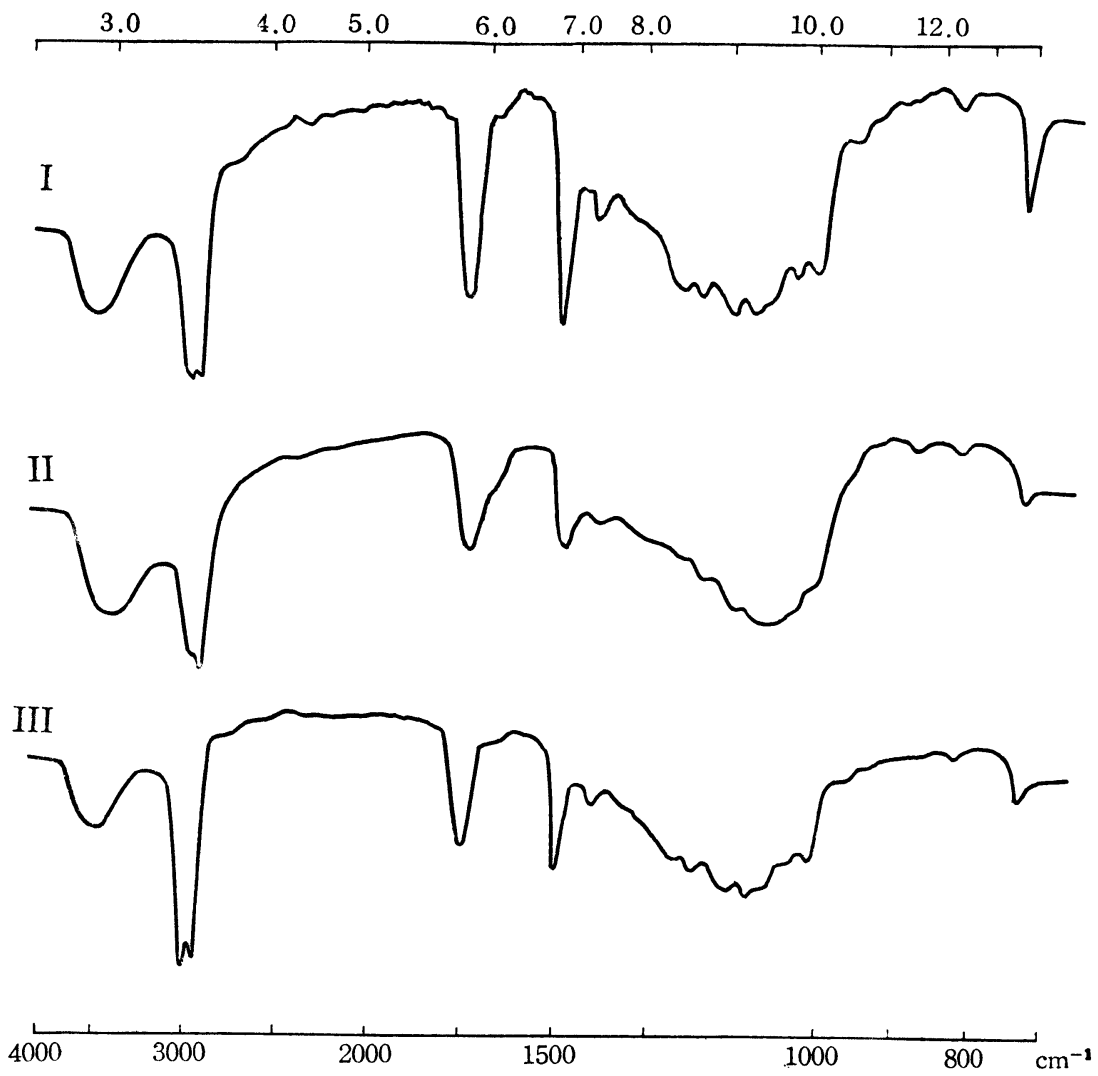

Fig. 1. Infrared spectra of cord factor fractions with three different lots of one week culture of BCG.

Some analytical data of the above substances are given in the following table

\begin{tabular}{cccccc}
\hline Substance & Lot No. & Tube No. of Chromatography & m.p. ${ }^{\circ} \mathrm{C}$ & $\mathrm{P} \mathrm{\%}$ & $\mathrm{N} \%$ \\
\hline I & $1 \mathrm{w}-1$ & $4\left(\mathrm{CHCl}_{3}-\mathrm{CH}_{3} \mathrm{OH} 93: 7\right)$ & $44-44.5$ & 0.31 & 0.01 \\
see Table 4 & Wax D (Table 1) & $46.5-52.5$ & 0.31 & 0.33 \\
II & $1 \mathrm{w}-2$ & $3^{*}\left(\mathrm{CHCl}_{3}-\mathrm{CH}_{3} \mathrm{OH} \mathrm{98:2)}\right.$ & $43-45$ & 0.29 & 0.10 \\
III & $1 \mathrm{w}-3$ &
\end{tabular}

* The same chromatographic partitioning as in the case of $1 \mathrm{w}-1$ was carried out.

The exact positions of infrared absorption maxima expressed in $\mathrm{cm}^{-1}$ were given as follows :

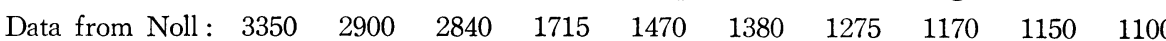

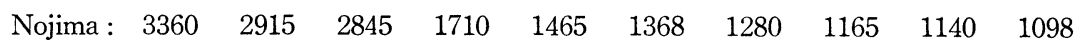

$\begin{array}{lllllllllll}\text { Present data : } & 3420 & 2915 & 2840 & 1715 & 1468 & 1368 & ? & 1170 & 1145 & 1075\end{array}$

Data from Noll : $\begin{array}{llllll}1050 & 1020 & 995 & 915 & 805 & 720\end{array}$

Nojima : $\begin{array}{llllll}1048 & 1013 & 985 & 925 & 790 & 711\end{array}$

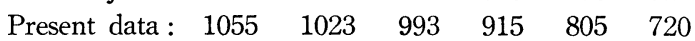


Table 5. Yield of cord factor in Wax D of $1 \mathrm{w}$ BCG as compared with that in 4 weeks culture

\begin{tabular}{ccccc}
\hline \multirow{2}{*}{ Culture } & $\begin{array}{c}\text { Wax D yield \% to } \\
\text { dry weight of } \\
\text { bacterial cells }\end{array}$ & $\begin{array}{c}c \\
\text { Yield \% to } \\
\text { Wax D }\end{array}$ & $\begin{array}{c}\text { Yield \% to dry weight } \\
\text { of bacterial cells }\end{array}$ & $\begin{array}{c}\text { Hexose content } \\
\text { in } \begin{array}{c}\text { Wax C } \\
\%\end{array}\end{array}$ \\
\cline { 3 - 5 } $4 \mathrm{w}^{*}$ & 1.5 & $\begin{array}{c}41 \\
\text { (average) }\end{array}$ & 0.61 & 0 \\
$1 \mathrm{w}-1$ & 0.8 & 79 & 0.63 & 0.58 \\
$1 \mathrm{w}-2$ & 0.5 & $c a .100$ & 0.5 & 1.09 \\
$1 \mathrm{w}-3$ & 2.0 & 31 & 0.62 & 0.50 \\
\hline
\end{tabular}

* cited from Nojima (1959a)

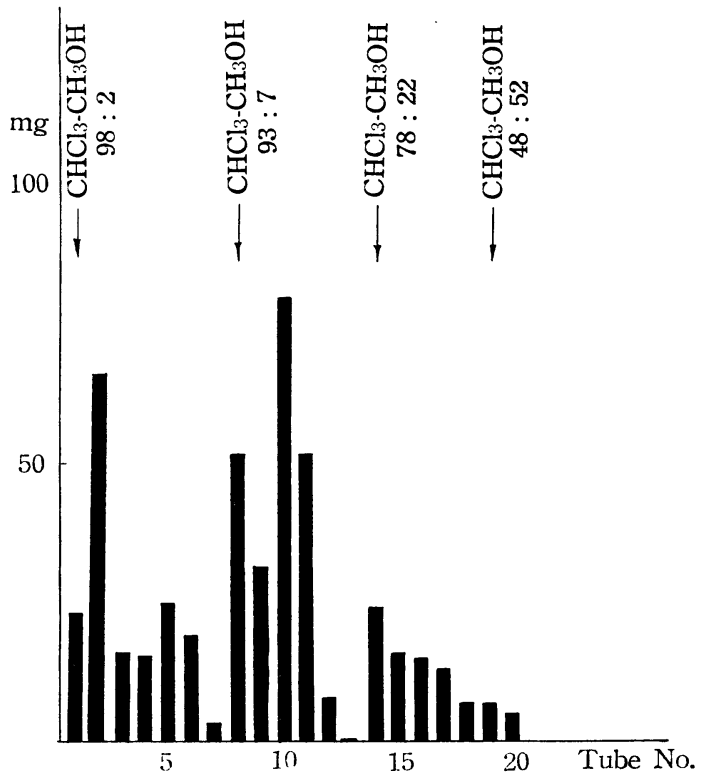

Fig. 2. Chromatography of $0.45 \mathrm{~g}$ of phosphatide of $1 \mathrm{w}-\mathrm{BCG}$ dissolved in chloroform, absorbed on $20 \mathrm{~g}$ of Silicic acid and $10 \mathrm{~g}$ of Hyflosupercel.

Each fraction of one week culture was shown to contain a considerable amount of phosphorus. The smaller amount of phosphorus in $4 \mathrm{w}$-No. 2 (Table 6) may be due to the presence of a large amount of glyceryl monomycolate therein (Kondo, 1960).

\section{DISCUSSION}

The total amount of lipid from one week culture of BCG was far less $(9 \%$ in Table 1) than that of 4 weeks culture (25\% in Table 1$)$. It is mainly due to the increase of neutral fat in 4 weeks culture $(12 \%$ in Table 1$)$ in parallel with the age of the culture $\left(\mathrm{lw}^{-1}: 3.9 \% ; \mathrm{lw}-2: 4.4 \%: 1 \mathrm{w}-3: 2.2 \%\right.$ in Table 1$)$. 


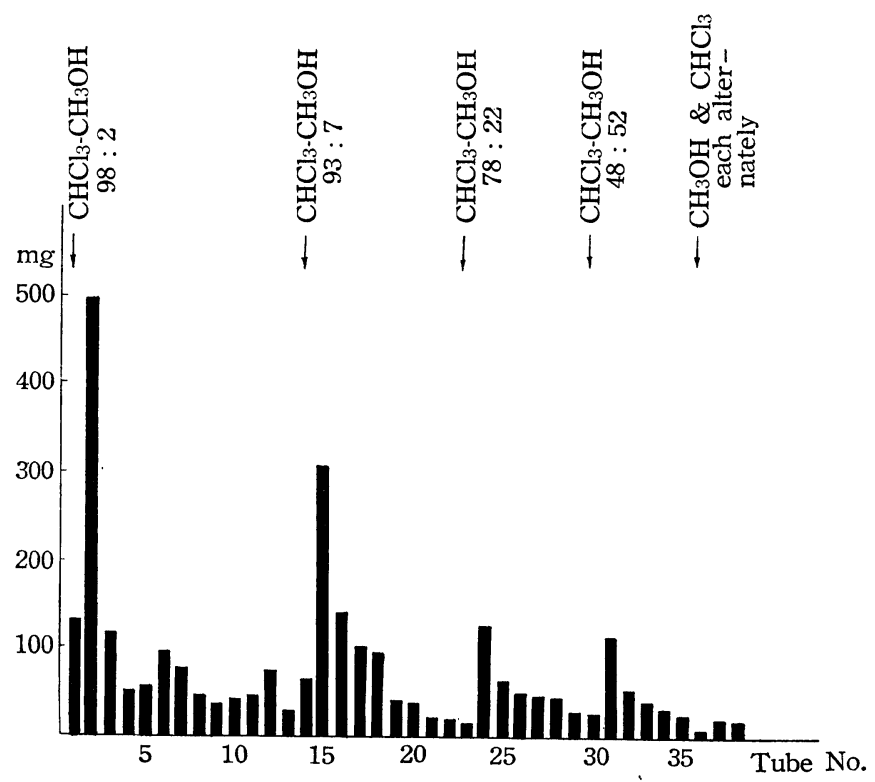

Fig. 2. Chromatography of $2.9 \mathrm{~g}$ of phosphatide of $4 \mathrm{w}-\mathrm{BCG}$ dissolved in chloroform, absorbed on $60 \mathrm{~g}$ of Silicic acid and $30 \mathrm{~g}$ of Hyflosupercel.

Table 6. Several analytical data of those tubes of maximum yield in three main peaks of phosphatide ( $1 \mathrm{w}$ and $4 \mathrm{w}$ ) chromatographed on Silicic acid and Hyflosupercel $(2: 1)$

\begin{tabular}{|c|c|c|c|c|c|c|c|c|c|}
\hline \multicolumn{5}{|c|}{$1 w$} & \multicolumn{5}{|c|}{$4 w$} \\
\hline $\begin{array}{l}\text { Tube } \\
\text { No. }\end{array}$ & $\mathrm{mp} .{ }^{\circ} \mathrm{C}$ & P \% & $\begin{array}{c}\text { Glycerol } \\
\%\end{array}$ & $\begin{array}{c}\text { Inositol } \\
\%\end{array}$ & $\begin{array}{l}\text { Tube } \\
\text { No. }\end{array}$ & $\mathrm{mp} .{ }^{\circ} \mathrm{C}$ & P $\%$ & $\begin{array}{c}\text { Glycerol } \\
\%\end{array}$ & $\begin{array}{c}\text { Inositol } \\
\%\end{array}$ \\
\hline 2 & 118 & 2.95 & 13.78 & 0.00 & 2 & $40-46$ & 0.43 & 6.91 & 0.00 \\
\hline 10 & $<27$ & 3.00 & 12.17 & 0.92 & 15 & $127-170$ & 1.84 & 10.13 & 0.00 \\
\hline 14 & $\begin{array}{c}160 \\
\text { (decomp.) }\end{array}$ & 4.90 & 15.22 & 3.73 & 24 & $>240$ & 5.98 & 6.67 & 0.61 \\
\hline
\end{tabular}

Details of chromatography are illustrated in Figs. 2 and 3.

On the other hand, the lipid-phosphorus content of one week culture of BCG is greater than that of 4 weeks culture, especially in the sum of "phosphatide" $-\mathrm{P}$ and Wax D-P (Table 2).

Table 5 showed that the cord factor content remains constant regardless of the culture age. It seems that this contradicts the common knowledge (e.g. Noll \& Bloch, 1953, 1955) that the cord factor (Wax C) content is greater in young than in old culture. But their data using a virulent human type of bacilli were obtained by the comparison of 2 to 3 weeks old (probably in logarithmic phase) with 12 weeks old (probably in stationary to declining phase) bacilli, while ours using BCG were one week (logarithmic phase) versus 4 weeks (stationary to declining phase) culture. 


\section{SUMMARY}

1. Lipid fractions, especially "phosphatide" and Wax D, fractionated by AndersonLederer method from one week culture of BCG, were isolated and analyzed for some chemical behaviours which were compared with those of 4 weeks culture.

2. Neutral fat content of 4 weeks culture was much higher than that of one week culture, resulting in that the amount of total lipid was far greater in 4 weeks culture than in one week culture.

3. The sum of phosphorus contents in Wax D and "phosphatide" was much larger in one week culture than in 4 weeks culture.

4. The cord factor content remained constant regardless of the culture age.

The author is greatly indebted to Drs. D. Mizuno and S. Nojima for their advices and discussion in carrying out this work.

\section{REFERENCES}

Anderson, R. J. (1929): The chemistry of the lipids of tubercle bacilli. IV. Concerning the so called tubercle bacilli wax. Analysis of the purified Wax. J. Biol. Chem., 83, 502-522.

Asselineau, J. (1951): Thèse doctorat ès Sciences, Paris. Acid mycoliques et cires du Bacille tuberculeux.

KONDO, E. (1960): Isolation and identification of glyceryl monomycolate and of mycolic acid in phosphatide fraction of BCG. Jap. J. M. Sc. \& Biol., 13, 161-163.

NoJimA, S. (1959a): Studies on the chemistry of Wax D of BCG. I. Fractionation of Wax D of BCG : Isolation of cord factor and oligomannoinositides. J. J. Biochem., 46, 499-506.

NoJimA, S. (1959b): Studies on the chemistry of Wax D. II. On the chemical structure of oligomannoinositide J. Biochem., 46, 607-620.

Nojima, S., Kondo, E. \& Mizuno, D. (1958): Distribution of inositol in the fractions of lipides from BCG. J. Biochem., 45, 475-480.

NoLL, H. \& BLOCH (1953): A toxic lipid component of tubercle bacillus (cord factor). II. Occurrence in chloroform extracts of young and old bacterial cultures. Am. Rev. Tuberc., 67, 828-852.

NolL, H. \& BLOCH (1955): Studies on the chemistry of the cord factor of Mycobacterium tuberculosis. J. Biol Chem., 214, 251-265.

Tsumita, T. (1956a): Studies on the lipid of BCG. I. Glyceryl monomycolate in Wax C fraction of the lipid BCG. Jap. J. M. Sc. \& Biol., 9, 205-216.

TsumitA, T. (1956): Studies on the lipid of BCG. II. On the mycolic acid of Wax A fraction of BCG. Jap. J. M. Sc. \& Biol., 9, 217-222. 